\title{
ANALISIS BREAK EVEN POINT PADA USAHA KERIPIK SINGKONG "BAROKAH" DESA KARANG REJO KABUPATEN PESAWARAN
}

\author{
Suharto \\ Bidang Rekayasa PP TELIMEK LAMPUNG-LIPI \\ (Rekayasa TELIMEK-LIPI)
}

\section{ABSTRACT:}

The purpose of an established business is to obtain profit or profit that can be used for survival. Likewise with the business of cassava chips "Barokah" in Karang Rejo Village Pesuat Pesawaran.Penelitian aims to find out how the value of Break Even Point aatu point home principal. This analysis is one of the tools used by the management company to be able to help in knowing how big a certain sales level, so the company does not get a profit and also not experience a loss (breakeven).

The type of research used in this research is descriptive research with quantitative approach, the data source used is secondary data. Based on the results of the analysis can be seen that the BEP value of cassava chips business "Barokah" in the unit of $862 \mathrm{~kg}$ and if stated in ruiah of $R p$. 10.185.454.

Keywords: Break Even Point, Fixed Cost, Variable Cost

\section{PENDAHULUAN}

\subsection{Latar Belakang}

Keripik singkong "Barokah" merupakan salah satu UKM yang ada di Desa Karang Rejo kecamatan Negeri Katon kabupaten Pesawaran. Usaha ini dirintis oleh Bapak Sunarto yang dibantu oleh sang istri dalam menjalankan usahanya. Tujuan dari sebuah usaha didirikan adalah untuk memperoleh keuntungan atau laba yang dapat dipergunakan untuk kelangsungan hidup. Namun, perkembangan dan kemajuan dunia usaha telah menimbulkan persaingan yang semakin ketat, sedangkan upaya untuk memperoleh laba tidak dapat dipisahkan dari masalah penjualan.

Pada umumnya suatu perusahaan dalam operasinya terlebih dahulu melakukan penjualan yang akan dicapai dalam tahun anggaran. Disamping itu, dalam pencapaian target penjualan tersebut, manajemen memerlukan informasi berupa volume penjualan minimum agar kegiatan usaha perusaan tidak lagi mengalami kerugian, atau kalau misalnya volume penjualan yang ditargetkan tidak tercapai, seberapa banyak turunnya target penjualan tersebut yang tidak mengakibatkan timbulnya kerugian dalam usaha perusahaan. Dalam hal ini salah satu alat bantu yang digunakan manajemen adalah analisis break event point, yang merupakan bagian dari analisis biaya-volume-laba. Menurut Sigit (2002) yang dikuti oleh Wijayanti, dkk., analisis break even point adalah suatu alat atau teknik yang digunakan oleh manajemen 
untuk mengetahui tingkat penjualan tertentu perusahaan sehingga tidak mengalami laba dan tidak pula mengalami kerugian.

Analisis impas atau analisis hubungan biaya, volume, dan laba merupakan teknik untuk menggabungkan, mengkoordinasikan dan menafsirkan data produksi untuk membantu manajemen dalam mengambil keputusan. Impas diartikan keadaan suatu usaha yang tidak memperoleh laba dan tidak menderita rugi. Dapat pula dengan kata lain, suatu usaha di katakan impas jika pendapatan sama dengan jumlah biaya. Dengan demikian analisis impas (break even ) adalah suatu alat yang digunakan untuk mempelajari hubungan antara biaya tetap, biaya variabel, dan volume penjualan. Dengan diketahuinya titik impas tersebut dapat direncanakan tingkat-tingkat volume produksi atau volume penjualan yang akan mendatangkan keuntungan bagi perusahaan yang bersangkutan. Agar terhindar dari kerugian perusahaan harus dapat mengusahakan jumlah penjualan pada titik impas. Apabila volume penjualan tidak mencapai titik impas berarti perusahaan akan menderita rugi. Dengan demikian, analisis break even point dapat dipakai sebagai bahan pertimbangan bagi seorang manajer dalamembuat keputusan sehubungan dengan kegiatan penjualan atau produksi.

Berdasarkan dari latar belakang diatas, maka penulis tertarik untuk melakukan penelitian dengan judul Analisis Break Even Point Pada UsahaKeripik Singkong "Barokah" Desa Karang Rejo Kabupaten Pesawaran.

\subsection{Rumusan Masalah}

Rumusan masalah pada penelitian ini adalah berapa nilai Break Even Point Pada Usaha Keripik Singkong "Barokah" yang dinyatakan dalam unit dan rupiah.

\subsection{Tujuan Penelitian}

Tujuan dari penelitian ini adalah untuk mengetahui :

1. Jumlah minimum unit produk Usaha Keripik Singkong "Barokah" yang harus dijual agar tidak mengalami kerugian melalui perhitungan Break Even Point yang dinyatakan dalam unit

2. Jumlah minimum penjualan yang harus dilakukan pada Usaha Keripik Singkong "Barokah" agar tidak mengalami kerugian melalui perhitungan Break Even Point yang dinyatakan dalam rupiah.

\section{TINJAUAN PUSTAKA}

\subsection{Pengertian Analisis Break Even Point}

Analisis break even merupakan suatu analisis yang digunakan oleh manajer dalam mengambil sebuah keputusan. Analisis ini bertujuan untuk mengetahui kaitan antara biaya, volume penjualan, volume produksi yang nantinya untuk menentukan titik impas dimana perusahaan tidak mengalami kerugian maupun tidak mendapatkan keuntungan. Analisis break even point sangat membantu manajemen dalam berbagai hal, misalnya dalam masalah dampak pengurangan biaya tetap terhadap titik impas, atau dampak peningkatan harga terhadap laba. Analisis ini sangat berguna bagi manajemen di dalam perencanaan dan pengambilan keputusan.

Menurut Supriyono yang dikutip oleh Choiriyah, dkk., (2016) "Break even 
point atau sering disebut dengan impas atau pulang pokok merupakan suatu keadaan perusahaan dimana besarnya jumlah total penghasilan sama dengan jumlah total biaya yang dikeluarkan oleh perusahaan atau rugi labanya = nol". Sedangkan Harahap (2007:358) dalam Choiriyah, dkk., (2016) berpendapat bahwa, "break even point berarti suatu keadaan di mana perusahaan tidak mengalami laba dan juga tidak mengalami rugi, artinya seluruh biaya itu dapat ditutupi oleh penghasilan penjualan".

\subsection{Kegunaan Analisis Break Even Point (BEP)}

Menurut Kuswadi (2005), terdapat beberapa manfaat di dalam analisis break even point (BEP) bagi manajemen perusahaan, diantaranya yaitu :

1) Untuk mengetahui hubungan volume penjualan ( produksi), harga jual, biaya produksi dan biaya-biaya lain serta mengetahui laba rugi perusahaan.

2) Sebagai sarana merencanakan laba.

3) Sebagai alat pengendalian (controlling) kegiatan operasi yang sedang berjalan.

4) Sebagai bahan pertimbangan dalam menentukan harga jual.

5) Sebagai bahan pertimbangan dalam mengambil keputusan yang berkaitan dengan kebijakan perusahaan misalnya menentukan usaha yang perlu dihentikan atau yang harus tetap dijalankan ketika perusahaan dalam keadaan tidak mampu menutup biaya-biaya tunai.

\subsection{Keterbatasan Analisis Break Even Point (BEP)}

Ada beberapa keterbatasan yang perlu untuk diketahui dalam analisis break even point menurut Keown, dkk (2010) yang dikutip oleh Choiriyah, dkk (2016), adalah sebagai berkut:

a. Hubungan biaya, volume, laba diasumsikan meningkat secara linear.

b. Kurva total pendapatan (kurva penjualan) diasumsikan meningkat secara linearsesuai dengan volume output.

c. Diasumsikan perpaduan antara produksi dan penjualan relatif tetap.

d. Diagram break even dan perhitungan break even merupakan bentuk analisis statis.

\subsection{Metode Perhitungan Break Even Point}

1). Pendekatan Matematis

Menghitung break even point yang harus diketahui adalah jumlah total biaya tetap, biaya variabel per unit atau total variabel, hasil penjualan total atau harga jual per unit. Rumus yang dapat digunakan adalah sebagai berikut:

a) Break even point dalam unit (Khasmir, 2012)

$$
\mathrm{BEP}(\text { dalam unit })=\frac{F C}{p-V C / \text { wnit }}
$$

(b) Break even point dalam rupiah (Khasmir, 2012)

$$
\mathrm{BEP}(\text { dalam rupiah })=\frac{F C}{1-\frac{V C}{S}}
$$

\section{2). Pendekatan Grafik}

Pendekatan grafik menggambarkan hubungan antara volume penjualan dengan biaya yang dikeluarkan oleh perusahaan serta laba. Selain itu juga untuk mengetahui biaya tetap dan biaya variabel dan tingkat kerugian perusahaan (Sartono, 2010 dalam Wijayanti). Asumsi yang digunakan dalam analisis pulang pokok ini adalah bahwa harga jual, biaya variabel per unit adalah konstan. 


\subsection{Asumsi Dasar Analisis Break Even Point (BEP)}

Asumsi-asumsi yang mendasari analisis impas menurut Mulyadi dalam bukunya "Akuntansi Manajemen: Konsep, Manfaat dan Rekayasa" (2001:260) yang dikutip oleh Chiriyah, dkk (2016), adalah sebagai berikut:

a. Variabilitas biaya dianggapmendekati pola perilaku yang diramalkan.

b. Harga jual produk tidak berubah-ubah pada berbagai tingkat volume penjualan.

c. Kapasitas produksi pabrik dianggap secara relatif konstan.

d. Harga faktor-faktor produksi dianggap tidak berubah.

e. Efisiensi produksi dianggap tidak berubah.

f. Perubahan jumlah persediaan awal dan persediaan akhir tidak berpengaruh.

g. Komposisi produk yang dijual tidak berubah.

h. Satu-satunya faktor yang mempengaruhi biaya yaitu volume

\subsection{Biaya}

Biaya adalah kas dan setara kas yg digunakan untuk memperoleh manfaat atau keuntungan di masa yg akan datang atas pengorbanan dalam memproduksi barang atau jasa yang diharapkan (Purwanti dan Prawironegoro, 2013 dalam Choiriyah, dkk., 2016).

Bustami dan Nurlela (2013:23) dalam Choiriyah, dkk (2016), mendefinisikan bahwa, "Perilaku Biaya dapat diartikan sebagai perubahan dari suatu aktivitas bisnis".Biaya yang dikeluarkan oleh perusahaan yang berhubungan dengan perilaku biaya dapat dibagi menjadi 3 golongan yaitu:

\section{a. Biaya Tetap (Fixed Cost)}

Biaya tetap yaitu biaya yang telah dikeluarkan baik sebuah perusahaan tersebut beroperasional maupun tidak dengan jumlah total yang tidak dipengaruhi dengan volume kegiatan, dimana semakin banyak volume kegiatan atau produksi maka biaya per unit akan semakin rendah.

\section{b. Biaya Variabel (Variable Cost)}

Biaya variabel didefinisikan sebagai "biaya yang jumlah totalnya berubah secara proporsional bersamaan dengan berubahnya output aktivitas, dengan biaya per unitnya tetap dalam batas waktu tertentu.

\section{c. Biaya Semi variabel}

Biaya semivariabel dapat disebut juga dengan biaya campuran."Biaya semivariabel didefinisikan sebagai biaya yang memperlihatkan baik karakteristikkarakteristik dari biaya tetap maupun biaya variabel (Carter, 2009:70 dalam Choiriyah, dkk 2016).

\section{METODOLOGI PENELITIAN}

Sumber data yang dikumpulkan dalam penelitian ini adalah data sekunder yang merupakan data primer yang telah diolah lebih lanjut dan disajikan oleh pihak pengumpul atau pihak lain dalam bentuk tabel atau diagram. Data yang diperlukan yaitu data yang berkaitan dengan unsurunsur yang digunakan dalam melakukan perhitungan BEP seperti biaya tetap, biaya variabel, volume produksi dan harga jual. Dalam pengumpulan data untuk analisis penelitian ini dilakukan melalui dokumentasi dan studi pustaka.

Untuk menghitung besarnya penerimaan dalam keadaan mencapai break even point pada pengolahan tebu di 
Pabrik Gula Tasikmadu digunakan rumus sebagai berikut :

a. Perhitungan Break Even Point atas dasar unit

$\mathrm{BEP}($ dalam unit $)=\frac{F C}{p-V C}$

Dimana :

BEP (Q) : Jumlah unit/kuantitas

produk yang dihasilkan dan dijual

FC : Biaya tetap

$\mathrm{P} \quad$ : Harga jual produk/unit

VC : Biaya variabel/unit

b. Perhitungan Break even point dalam rupiah

$\operatorname{BEP}\left(\mathrm{Q}_{1}\right)=\frac{F C}{1-\frac{V C}{S}}$
Dimana :

Q1 : Volume penjualan produk keripik singkong dalam Rupiah

FC : Biaya tetap

VC : Biaya variabel

$\mathrm{S} \quad$ : Penerimaan (volume penjualan $\mathrm{x}$ harga jual per unit produk)

\section{HASIL DAN PEMBAHASAN}

Berikut ini merupakan hasil dari data yang diperoleh dari usaha keripik singkong "Barokah" yang telah diolah.

Tabel 1. Biaya Tetap Per Bulan dan Biaya Variabel per Kg

\begin{tabular}{|l|l|}
\hline Uraian & Keripik Singkong \\
\hline Biaya Variabel : & Rp. 4.500 \\
Biaya bahan baku & Rp. 3.000 \\
Biaya bahan penolong & Rp. 3.200 \\
Biayan Tenaga kerja langsung & Rp. 10.700 \\
\hline Total Biaya Variabel & \\
\hline Biaya Tetap : & Rp. 69.400 \\
Biaya Penyusutan Mesin & Rp. 1.000 .000 \\
Biaya Tenaga Kerja Tidak Langsung & Rp. 51.000 \\
Biaya listrik & \\
\hline Total Biaya Tetap & Rp. 1.120 .400 \\
\hline
\end{tabular}

Tabel 2. Rekap Data Biaya Tetap, Biaya Variabel dan Harga Jual

\begin{tabular}{|l|l|l|l|}
\hline Produk & Biaya Tetap & Biaya Variabel / kg & Harga Jual / kg \\
\hline Keripik Singkong & Rp. 1.120 .400 & Rp. $10.700 /$ kg & Rp. 12.000 / kg \\
\hline
\end{tabular}

Sumber : Data diolah 


\section{Pembahasan}

Break Even Point untuk keripik singkong dinyatakan dalam $\mathrm{kg}$

$\begin{array}{ll}\operatorname{BEP}(\mathrm{kg}) & =\frac{1.120,400}{12.000-10.700} \\ \operatorname{BEP}(\mathrm{kg}) & =\frac{1.120 .400}{1.300} \\ \operatorname{BEP}(\mathrm{kg}) & =862 \mathrm{~kg}\end{array}$

Break Even Point untuk keripik singkong dinyatakan dalam rupiah

$$
\begin{array}{ll}
\operatorname{BEP}(\mathrm{Rp}) & =\frac{1,120,400}{1-\frac{11,416,900}{12 \pi, 804,000}} \\
\operatorname{BEP}(\mathrm{Rp}) & =\frac{1,120,400}{1-0,89} \\
\operatorname{BEP}(\mathrm{Rp}) & =\frac{1,120,400}{0,11} \\
\operatorname{BEP}(\mathrm{Rp}) & =\text { Rp. } 10.185 .454
\end{array}
$$

Break even point atau sering disebut dengan titik impas atau pulang pokok merupakan suatu keadaan perusahaan dimana besarnya jumlah total penghasilan sama dengan jumlah total biaya yang dikeluarkan oleh perusahaan atau rugi labanya $=$ nol. Setelah proses analisis perhitungan break even point (BEP) menggunakan pendekatan matematis dilakukan berdasarkan data diterima sewaktu penelitian atau pengamatan terhadap Usaha Keripik Singkong "Barokah", diperoleh hasil analisis bahwa usaha keripik singkong "Barokah" untuk mencapai titik impas dalam penjualan rupiah produk keripik singkong harus mampu menjual hasil produknya sama dengan $\mathrm{Rp}$ 10.185.454 atau lebih dari penjualan tersebut dan untuk mencapai unit yang dapat dijual agar produk keripik singkong tidak menderita rugi maka harus mampu menjual $862 \mathrm{~kg}$ produk.

\section{KESIMPULAN DAN SARAN}

Berdasarkan analisis data dan pembahasan di atas, maka dapat diperoleh kesimpulan bahwa dalam menentukan break even point bagi setiap perusahaan, termasuk UKM merupakan salah satu perencanaan yang perlu dilakukan manajemen atau pemilik usaha. Karena dengan adanya perhitungan dan analisis BEP, biaya-biaya tetap dan variabel dapat diidentifikasi dengan baik, selain itu batasan minimal yang harus diproduksi atau dijual dapat dijadikan acuan bagi pemilik usaha untuk mampu mencapai bahkan melebihi nilai BEP yang ada agar tujuan perusahaan untuk memperoleh keuntungan guna menjaga kelangsungan usahanya dapat terpenuhi. Nilai BEP usaha keripik singkong "Barokah" dalam unit sebesar $862 \mathrm{~kg}$ dan jika dinyatakan dalam ruiah sebesar Rp. 10.185.454.

Saran yang diberikan peneliti adalah:

a. Kepada peneliti selanjutnya diharapkan melakukan pengembangan lebih lanjut dari penelitian ini dengan menggunakan objek perusahaan yang berbeda dan menambahkan variabel lain.

b. Kepada Usaha Keripik Singkong "Barokah" yaitu hasil analisis BEP yang ada dapat dijadikan masukan dan pertimbangan dalam melakukan kegiatan produksi, sehingga nilai BEP yang diperoleh sebaiknya menjadi standar volume yang harus diproduksi atau dijual setiap bulannya, karena mencerminkan keadaan impas, dimana total pendapatan sama dengan total biaya. 


\section{DAFTAR PUSTAKA}

[1] Choiriyah, Vivin Ulfathu., dkk., 2016, Analisis Break Even Point Sebagai Alat Perencanaan Penjualan Pada Tingkat Laba Yang Diharapkan (Studi Kasus Pada Perhutani Plywood Industri Kediri Tahun 2013-2014), Jurnal Administrasi Bisnis (JAB) Vol. .35 No. 1 Juni 2016 Fakultas Ilmu Administrasi Universitas Brawijaya

[2] Jumingan. 2008. Analisis Laporan Keuangan. Bumi Aksara. Jakart

[3] Kasmir. 2010. Pengantar Manajemen Keuangan. Prenada Media. Jakarta

[4] Kuswandi. 2005. Meningkatkan Laba Melalui Pendekatan Akuntansi Keuangan dan Akuntansi Biaya. Jakarta: PT Elex Media Komputindo

[5] Lili M. Sadeli dan Bedjo Siswanto. 2004. Akuntansi Manajemen. Bumi Aksara. Jakarta

[6] Marhaeni Agustina Pradita. 2011. Analisis Break Even Point Sebagai Alat Perencanaan Laba Pada Industri Kecil Tegal di Kecamatan Pedurungan Periode 2004-2008 (Studi Kasus Usaha Manufaktur) . Skripsi. Fakultas Ekonomi Universitas Diponegoro.

[7] Pusat Pendidikan dan Pelatihan Industri Kementerian Perindustrian. Modul Studi Kelayakan Bisnis Program Kewirausahaan TPL Beasiswa, Jakarta;

[8] Wijayanti, Suci Mulya, dkk., Analisis Break Even Point Sebagai Salah Satu Alat Perencanaan Penjualan Dan Laba (Studi Pada Pt. Ultrajaya Milk Industry \& Trading Company, Tbk) , Universitas Brawijaya 